\title{
THE UNNATURALNESS OF A SOCIETY: CLASS DIVISION AND CONFLICT IN SYLVIA TOWNSEND WARNER'S KINGDOMS OF ELFIN
}

\author{
Hannah Priest
}

Sylvia Townsend Warner's collection of fairy stories, Kingdoms of Elfin, opens with 'The One and the Other', the tale of two children - one fairy and one mortal - who are switched at birth by the elfin of Elfhame. The abduction of the human is described starkly: '[w]hen the baby was lifted from the cradle, he began to whimper' (Warner, 1979 p.1). It is apparent from the opening paragraphs of the story that this is not the first human child to be taken by the fairies; moreover, the elfin show little sentimentality. Queen Tiphaine expresses sadness that mortal children grow old, and we learn that she has already 'exhausted a good many human babies' (p.1). As the story progresses, Tiphaine makes a favourite out of the changeling, naming him Tiffany, before expelling him from Elfhame as soon as his hair begins to turn grey. Tiffany's fate is that of all changelings: he is returned to the mortal world as a hopeless and helpless old man. Meanwhile, Adam, the fairy child left with the mortal family, grows into a strange and callous man. He becomes obsessed with death and horrifies his nurse by wordlessly dissecting the cat that had suckled him as child. 
Eventually, Adam's quest to discover the meaning of death leads him to study fairy legends. He becomes convinced that the secret of immortality - 'magnetic air' can be found in fairy blood (p.11). He arrives at the inn where the aged Tiffany is housed, and overhears the old man raving about Elfhame. Adam draws blood from Tiffany, but discovers nothing of interest. He then notices that he has botched the phlebotomy and that Adam has bled to death. The story ends with Adam's assessment of the dead man:

So the poor wretch was not a fairy; and the bedding would have to be paid for. But if the body could be got to the anatomists in Edinburgh, thought Adam, taking heart again, I shall break about even.

(p.14)

Adam's actions in this story, like those of the fairies who abduct children, are not presented as deliberately malicious, but they lack morality or conscience. This elfin amorality can also be seen in 'Winged Creatures'. In this story, Lady Fidès of Bourrasque gives birth to a child, though she has no connection with - or recollection of the boy's father. The only interest Fidès shows in the child comes from her obsessive ornithology; she first plans to teach her baby about birds, then dreams that he might become one. When the child Grive fails to fly, and destroys Fidès' hopes of transforming him into a bird, she rejects any further maternal sentiment: 'She could never feel love for him. Love was what she felt for birds - a free gift, unrequired, unrequited, invulnerable' (Warner, 1979 pp.121-2). Fidès' callousness is a reflection of the kingdom as a whole. 'Winged Creatures' also features a cast-out changeling, Gobelet, who is 'left to beg his way through the world and die in a ditch with the crows standing round like mourners, waiting to peck out his eyes' (p.123). Moreover, shortly after the expulsion of Gobelet, a plague hits the tenants of the kingdom, depriving the gentry fairies of the food and '[f]uel dues' usually provided by their 'serfs' ( $p p .124-5)$. Despairing of 
the situation, the Bourrasque court decides to leave the area and settle elsewhere, viewing the deaths of both 'serfs' and cattle as an inconvenience they would rather do without. The court fairies pack up their belongings, while those left behind starve and die. As Fidès leaves the court, she does not take Grive with her. This is not an act of malice or deliberate harm - the fairy has simply forgotten that she has a son.

- Warner's presentation of the amorality of fairies is by no means unique. The cruelty of fairies is a theme which runs through folklore and literature. Diane Purkiss argues that 'fairies are an invention that almost wholly lacks moral engagement' (Purkiss, 2001 p. 8). From Shakespeare's Titania and Oberon to Barrie's Peter Pan and Tinker Bell, fairy literature abounds with imperious and thoughtless creatures that use mortals simply for sport, and treat one another in much the same way. However, though Warner undoubtedly draws on this tradition in creating her elfin, these creations are not ahistorical. They are rooted in a set of social and cultural concerns that are visible elsewhere in Warner's writing. As Jack Zipes says of fairy tales in general, the Kingdoms of Elfin contain 'a symbolical reflection of real sociopolitical issues and conflicts' (Zipes, 2002 p. 43). The symbolism of this reflection is not one of straightforward correspondence, but it is nevertheless possible to trace 'real' concerns in the 'fantasies' of Elfin.

Though Fidès' 'inhuman' treatment of her son takes up the foreground in 'Winged Creatures', it is important not to ignore the backdrop for this rejection. The court of Bourrasque is sustained by, and built upon, a hierarchical relationship between aristocracy and serfdom. While the pestilence is, on the whole, described from the point of view of the court, Warner leaves her reader in no doubt as to the devastation it entails for the peasantry. The plague reveals imbedded social injustice, which is not lost on the disease-ridden masses who 'railed against the palace people, who had done nothing for them, feasted while they starved, danced while they were dying, deserted them' (Warner, 1979, p.128). This injustice resonates 
with the rhetoric of revolutionary France and Russia. Like the aristos of the ancien régime, the French court of Bourrasque shows no concern for the suffering lower classes.

The aristocracy of Warner's fairies is apparent throughout the narratives. Although there are references to the flying 'working' fairies who act as servants and retainers, almost all the stories centre on regal or noble characters. Despite their 'inversion' of Salic law, elfin kingdoms function through feudal relationships clearly comparable to European systems of power. Moreover, like the European aristocracy, elfin structures of power are neither timeless nor universal. They have a history, as can be seen in 'Visitors to a Castle' where the name Castle Ash Grove is said to hark 'back to a time when its inhabitants did not care to build and had not developed a social hierarchy of flying servants, strolling gentry" (Warner, 1979, p.93). Thus, the rigid and formal dictates of elfin culture are the product of centuries of social stratification. It is also clear that a process of naturalization has occurred, as elfin draw on the traditions of spurious ancestors to affirm the status quo. The arbitrariness of such 'traditions' is revealed at points in the stories, adding to a sense that the aristocratic fairies construct their past in order to maintain their present. For example, in 'The Revolt at Brocéliande', queens reinforce their position as monarchs by periodically reviving customs from their 'Persian' forebears. Queen Melior decides to reintroduce the 'tradition' of court eunuchs, and has two changeling boys castrated. When the fairies grow bored of them, the eunuchs are treated as little more than animals, forced to compete in a 'eunuch fight' while the elfin await a delivery of fighting cocks (Warner, 1979, p.62). The fate of $\mathrm{Ib}$ and Rollo parallels that of the Royal Werewolves in another of the Brocéliande stories, introduced as a 'tradition', but dropped, almost at random, when they fall out of favour. The fickleness of the elfin can be seen clearly in the judgement on the werewolves: 
[V]arious arguments were put forward: they were a traditional glory; they were quite out of date; no one wanted them; they were the envy of every other court. Melior seemed to incline to the traditionalists; then, for she prided herself on her spontaneity, passed the death sentence. They were hanged.

(Warner, 1979, p.89).

Melior's act of caprice is worthy of a fairy queen; however, it also speaks to the ways in which the European aristocracy long relied on recourse to a constructed past and the visible exercise of absolute power to maintain its position. The insistence on the importance of keeping up the appearance of 'glory' in Brocéliande, and the ruthless absurdity of the fairy fashions, reveal a socio-political concern in Warner's stories that goes beyond simply an adherence to 'a vogue for all things fay' (Simons, 2006, p.56) ${ }^{1}$.

If the elfin are the aristocracy, mortals are their lower class counterparts. Just as very few of the stories are concerned with non-gentry fairies, Warner's works are also devoid of aristocratic humans. Throughout the tales, mortals are presented as almost universally working class, pragmatic and fertile. For instance, in 'The One and the Other', the hard-working Mrs. Tod does not notice that her child has been exchanged for a fairy as she is too busy baking bread. Elfin are keen to use this characterization of mortals to reinforce their own superiority. They argue that the custom of taking changelings is, in fact, beneficial to the stolen children: 'They grow up as court playthings, fondled, indulged, and kept much cleaner than they would be in human homes' (Warner, 1979, p.58). This inherent difference also explains the mortal inclination to religion:

They lead such unsatisfactory lives. They are so short-lived, and so prolific. They see their children dying by the dozen and in the twinkling of an eye are dead themselves. So 
they avenge themselves on their limitations by thinking there's more to it than that.

(Warner, 1979, p.172).

This derision of the mortal condition in 'The Late Sir Glamie' is, however, coupled with a fear of miscegenation and contamination. When the ghost of Sir Glamie continues to haunt the Court of Rings, the elfin suspect it is due to his being part-mortal - as soulless fairies do not have a life after death. Although several stories in the Kingdoms of Elfin make reference to sexual encounters between fairies and humans, this story presents inter-species breeding as a source of serious anxiety:

Therefore, at some point or other of Sir Glamie's pedigree an Elfin lady must have yielded to a mortal lover, and immortality, like the pox, has run in the family ever since. [...] Most painful of all was the threat to the calm negation on which all Elfindom reposes. Once this was undermined by Sir Glamie's reappearances, libertine speculations and surmises would widen the breach, superstition, proselytizing, fear of an awaiting life after death, would rush in, and Elfins sink to the level of mortals.

(Warner 1979, p.170).

The superiority of the fairy race depends on its purity. Any inter-breeding with humans could result in them 'sinking' to the level of the lower classes. As Helen Sutherland writes, "the mechanisms for creating and maintaining social distinctions are all too familiar' (Sutherland, 2005, p.25). We can recognize, in the fairy/mortal division, the entrenched class systems of Western Europe.

Warner is not unusual in using fairy literature to hold a mirror to socio-political mechanisms of power. However, her Kingdoms of Elfin stories are not fables intended to 
romanticize or reinforce the class system. They are not designed, as Diane Purkiss argues much fairy literature was, as 'an edifice of fantasy' about 'a past in which servants knew their place and aristos knew theirs' (Purkiss, 2001, p. 185). Nor are Warner's fairies 'a sign of the Good Old Days, the Good Old World before whatever change the writer deplores' (Purkiss, 2001, p.164). Rather, Warner uses her elfin to explore social change and the (necessary) effect this has on the ossified gentry. In order to understand this fully, one must give closer examination to the mortal world which surrounds the Kingdoms of Elfin.

While the fairy world appears almost timeless and detached from human reality, many of Warner's stories include historical specificities which allow us to place them on a human timeline. For example, in "The Five Black Swans', Morel and Amanita's parents have been burned as heretics during the 'Easter festivities' in Madrid (Warner, 1979, p.18). This reference to the auto-da-fé of the Spanish Inquisition sets the story in the seventeenth century. ${ }^{2}$ Elsewhere, the fairy Hamlet attends early performances of Shakespeare's plays; a fairy court is disrupted by the 'Killing Times' of seventeenth-century Scotland; and, in a clear reference to the Scottish writer James Hogg (1770-1835) - known as the 'Ettrick Shepherd' - 'Jamie Hogg the shepherd' is disturbed by the noise of fairies collecting food . $^{3}$

Due to the fairies' longevity and lack of concern with the world of mortals, the passage of history is presented at times as utterly inconsequential or severely truncated. 'The Climate of Exile', for example, begins with an established fairy court moving in response to a perceived slight by the builders of Hadrian's wall; the cursory comment of '[f] $\mathrm{frther}$ centuries passed', with a dismissive mention of the 'wars, forays, cattle-raids and pilgrimages' of human history, signals a move into the seventeenth century (Warner, 1979, p.153). Within a sentence, 1500 years of mortal existence are glossed over - and the fairy court remains largely unchanged. 
Though the elfin refuse to acknowledge them, Warner frequently makes clear the violent and dramatic changes in the human world. References to the 'Killing Times' and the Spanish Inquisition allow readers to detach themselves from the elfin's scornful ignorance of religion and remember brutal conflicts and upheavals. In 'The Blameless Triangle', oblivious fairies fly over the evidence of bloody class conflicts along the Danube:

Sometimes the landscape was obliterated by smoke and they heard cannon fire. Once, alighting in the park, they found a burnedout mansion and a row of impaled cadavers tottering on a fence' (Warner, 1979, p.47).

These fairies are dissidents, seeking a new home after becoming disillusioned with courtly life. They settle in an area which they treat as a rural idyll, but there are clear indications that it is, in fact, far from idyllic: 'Workers were busy in the fields, with overseers among them, and at night the overseers kept watch, sitting in raised seats, each with a dog beside him' (p.48). As the fairy world remains in the stasis of its own perceived superiority, the march of mortal history continues.

This is most keenly depicted in 'Visitors to a Castle', the only Kingdoms of Elfin story which contains a precise 'human' date. The story begins with the arrival of an Irishman to the Welsh Kingdom of Castle Ash Grove. The man arrives on a piece of granite, which he has been able to use as a boat through an act of faith. Given this, and references to his subsequent career, it is probable that the visitor is St. Brynach, which would date the opening of the story to around $\mathrm{AD} 500$. Following their interaction with Brynach, the fairies of Castle Ash Grove embark upon a project to remove the mountain of Mynnydd Prescelly by singing. Again, there is a sense of the Elfin's detachment from human time, as they practice and hone their singing skills over what seems like weeks but is actually centuries. There is casual mention of 'five centuries' passing, and of Thomas Tomkins playing at 
Worcester Cathedral (c. 1621) and a performance of the Messiah at the Three Choirs' Festival (post-1759) (Warner, 1979, pp.96-7). However, it is left to readers to follow Warner's clues and date these events for themselves.

The narrative then breaks from the typical vagaries of Kingdoms of Elfin historical reference. It states: 'By now we are within sight of the twentieth century. It was a fine autumn evening in 1893' (p.97). This is the date of the second 'visitor' to the 'castle', a district nurse from Nottingham. Where Brynach had arrived on floating granite, the nurse arrives on a bicycle. The saint had spoken of faith and miracle; the 1893 visitor produces a large black medical bag and applies disinfectant to her wounds. The nurse deems the fairy court 'old-fashioned', and talks about 'lockjaw'(pp. 98, 99). The Elfin court is not prepared for such a visitor, and decides to effect her removal. Despite their apparent earlier success at removing Mynnedd Prescelly, their songs do nothing to shift the district nurse from 'Nottingum'. The story ends with the fairies travelling to Plynlimon in search of the 'Simple Life' of 'nature, nuts, sleeping out-of-doors, an escape from convention and formality' (p.100). Yet the spectre of the nurse follows them, and Dame Bronwen who had previously fainted at the smell of disinfectant is haunted by her memories of the visitor. When pressed by her queen to explain her distress, she describes the vision brought on by the "bad smell':

When I fainted it was because of what was shown me. I saw trees blighted and grass burned brown and birds falling out of the sky. I saw the end of our world, Morgan the end of Elfin. I saw the last fairy dying like a scorched insect.

(Warner, 1979 p. 102).

Whatever the myopic Elfin kingdoms believe, the mortal world has changed dramatically over the course of the centuries. Dame Bronwen's prediction indicates that 
the fairy court will be ill-fitted to deal with the arrival of the twentieth century. Though the Elfin were once feudal lords, they are now 'insects' to be burned away.

In fact, despite their unquestioning assumption of supremacy, Warner's fairies rarely do well in their dealings with mortals. In 'The Five Black Swans', the dying Queen Tiphaine fondly remembers her liaison with Thomas of Ercildoune in romantic terms: they meet on May Day; he has foreseen their encounter and searched long and hard for her; he brings her gifts and has written rhymes; they quarrel poetically; she never forgets him (Warner, 1979, pp.15-22). This centuries-old memory contrasts sharply with the encounter between a fairy lady and a mortal man in 'Castor and Pollux'. Here, Nel meets a mortal actor and gives him her ring as a keepsake. While Nel plays the part of the imperious fairy lover, the actor sees her as 'one of those grand ladies, shameless and glorious', with whom he is clearly very familiar (Warner, 1979 p.179). Nel is caught by her uncle 'with her heels in the air' and the 'dirty marauding mortal' is shooed off by a gardener with a hoe (p.180). There is none of the high romance of Tiphaine's affair with True Thomas, and Nel's undignified fumble results in an unwanted pregnancy, a failed abortion and death, as giving birth to half-mortal twins 'rent her in pieces' ( p.180).

Elsewhere in the Kingdoms of Elfin, fairies are treated with contempt and condescension by mortals. In 'Elphenor and Weasel', a fairy meets Master Blackbone, who tells him:

There were fairies all round my father's place in Suffolk. Thieving pests, they were, bad as gipsies. But I half liked them. They were company for me, being an only child. (Warner, 1979, p. 24).

Aristocratic fairies are reduced simultaneously to the mischievous tricksters of folktales and the harmless playthings of children's stories. And why should they not be? Throughout Warner's stories, fairies make use of their 
invisibility to steal from mortals. When confronted by humans, they resort to pinching and nipping. While they are able to snatch children, effect the odd death, and loot shipwrecked vessels, fairies have little power over the human world. The Elfin narrative of refined, powerful fairies and ignorant, peasant humans is revealed as a 'fairy tale', told and retold in order to reify the class distinction.

Nevertheless, the Elfin cling to their deeply-held conviction of superiority - with sometimes disastrous consequences. In 'Narrative of Events Preceding the Death of Queen Ermine', mortals arrive to mine iron on Tut Hill, near the Kingdom of Deuce. The fairies are divided as to whether or not this is a problem. Sir Haggard argues that it is and "claimed that territorial rights extended downward - adding that if kingdoms lay on the surface like carpets they could as easily as carpets be rolled up' (Warner, 1985, p. 148). Others blithely assume that there is no point confronting the humans, as the mortal endeavour would - like all mortal endeavours - pass with time. The mining project develops, and begins to have an impact on the world of the Elfin. Their winter celebrations - recognizable as 'traditional' feudal festivities - are the first thing to be affected:

The Yule log was borne into the hall [...] the apple trees were wassailed and apple dumplings distributed to the grateful tenantry - a mingled yarn of mortals, halfcasts and changelings. If they did not seem so grateful as usual, this was nothing out of the common: they seldom did.

(Warner, 1985, pp.148-149).

The fairies ignore the first signs of discontent amongst their tenants, but this is soon followed by mortal children trespassing on Elfin land. Though the fairies attempt to deter them with pinching and poisoning, Sir Haggard warns that this will do little to alleviate the situation, referring back to the fairy staple of high mortal fertility 
rates: 'Far from discouraging the mortals at Tut Hill, the policy of child-eradication would inevitably lead to every child under a useful age being driven into the Great Park to meet its end' (p.149). Worse still, the 'tenantry' become disillusioned with the feudal world of Elfin, and are '[c]orrupted by the vicinity of wage-earning mortals', leaving Deuce for work at the pit (p.150).

Although a somewhat absurd figure, Sir Haggard is the only fairy who even partly comprehends the reality of what is happening. He attempts to deal with the problem in a rather 'human' way: he approaches the mine-owner and demands rent, and he joins the Board of Directors of the mine in an attempt to persuade them to cease drilling. Despite some awareness, though, Sir Haggard is woefully out-of-touch with the world of the humans. His appeals to human conscience, and his assertion of the undesirability of iron (when compared with potatoes), shows that he has no conception of industrialized society. $\mathrm{He}$ is gently mocked by the other directors, who treat him as a 'mascot' (p.158). Eventually, Queen Ermine and her followers decide to leave Deuce, but before they can do so, there is an explosion at the pit and the subsequent flooding kills the fairy procession. The only Elfin left alive are those who sided with Sir Haggard, and recognized the threat that the mine caused. Just as Dame Bronwen foresaw in 'Visitors to a Castle', the modern mortal world has killed the fairies.

So what is one to make of these impotent, feudal fairies, desperately clinging to an outdated and redundant way of life? Are we to see them as an allegory of the upper classes and cheer when they are brushed aside by the resilient and progressive world of the working class? It is hard to have sympathy for the feasting gentry of Bourrasque who coldly allow the peasants to die of plague. However, it is equally difficult not to feel a certain nostalgic sadness as Dame Bronwen foresees the end of Elfin. While the pit disaster at Tut Hill wipes out the supposed feudal overlords, it also kills many of the human workers; the scene is one of misery, as the employees struggle to come to terms with a devastating 
industrial accident. Though the world of the fairy is one of hierarchy and class distinction, the mortal world is one of violence, confusion and death.

The Kingdoms of Elfin stories are an ambivalent response to class distinction and conflict. In this respect, the stories bear some comparison with Warner's earlier historical novel, Summer Will Show (1936). In this novel, the disillusioned and unhappy Sophia Willoughby travels to Paris with the idea of getting pregnant by her estranged husband. Once in France, she becomes involved with the revolution of 1848 , enters into a relationship with her husband's mistress, Minna Lemuel, and forms tenuous and sometimes unfulfilling - links with various Communist factions. Sophia's experience as a member of the nineteenth-century English upper classes is one of impotence and futility. She exercises what she sees as her birthright by expelling her unfaithful husband, but this leaves her with status but no power:
And her peculiar freedom, well-incomed, dishusbanded, seemed now only to increase the impotence of her life. Free as she might be to do as she pleased, all her doings were barrened.
(Warner, 1987. p.53).

Until she meets Minna, Sophia's life seems destined to be one of 'futility, rage and regret' (p.139). Once involved in the Parisian revolt, Sophia seems to find purpose and (almost) happiness, and becomes a tentative critic of the world in which she was brought up.

Yet the alternative to Sophia's stifled gentry life is one of suffering and deprivation, into which she still does not 'fit'. In the end, though she becomes reluctantly willing to die for a cause, her nobility denies her even that. The revolution is dismissed as misguided; Minna dies fighting. Like Sir Haggard, Sophia is left having renounced the old way of life, but unsure as to what the new world should be. Sir Haggard does not return to the ruins of Deuce; Sophia does not return to her Aunt Léocardie's home. Neither text leaves the reader with a clear sense the 
future, but both offer an insupportable past blown away by an insecure present.

However, while Summer Will Show ends with Sophia becoming absorbed in the Communist treatise she has helped distribute, Kingdoms of Elfin presents us with a number of fairies who settle into a kind of cosy capitalism. Indeed, it is the fairies who accept and embrace the mortal mercantile world who succeed and survive. In 'Castor and Pollux', Hamlet ensures that he can have an impact on the human world by acting as an 'anonymous patron' of the arts; the fairy Caraway goes further, and buys a bank which is 'useful as a source of mortal specie when fairy gold was not negotiable' (Warner, 1979, p. 178; 189). As noted, Sir Haggard's attempts to enter into the industrial world of the humans entail his survival when the other fairies perish. As Robert Crossley notes, 'Warner's sympathies do not lie with the elfin temperament, but in understanding elfins as human opposites she invites a richer appreciation for, a deeper contentment with the human condition.' (1985, p.65) While Warner's contemporary, J.R.R. Tolkien, may have used elves to 'project utopian visions of better worlds which human beings are capable of realizing with their own powers' (Zipes, 2002 p.149), Warner's Elfin stories resist both utopian projection and nostalgic retrospection. The fantasy world of Kingdoms of Elfin is one of class distinction and division, but also of negotiation and compromise.

Warner's Elfin stories belong to a long tradition of fairy literature in English that uses supernatural creatures to explore social, political and cultural concerns. Purkiss argues that '[f]airies become an empty space as oral traditions fade, and hence become a space for thinking about difference' (2001, p.209). Warner's fairy stories are undoubtedly concerned with "thinking about difference"; nevertheless, as the examples I have given throughout this article demonstrate, they are also tales of the absurd, the whimsical and the seductive. While I have shown that these stories can be read as reflections of European sociopolitical history, many other readers see something quite 
different in the stories. The front cover of the Penguin edition of Kingdoms of Elfin offers the tagline: 'Strange tales of the fantastic, the sinister and the impossible.' These tales are at once escapism with a serious heart and frivolous social commentary. I suggest that it is this contradictory element, this possibility of reading the stories in multiple ways, which makes Kingdoms of Elfin an example of fantasy literature at its strongest and most powerful.

\section{NOTES}

1. Simons here argues that Kingdoms of Elfin can be seen as contemporary fiction which 'speaks to its period' due to the fashion in the 1960s and 1970s for tales involving fairy creatures.

2. This is also the temporal backdrop for 'The Climate of Exile', in which the fairies attend the auto-da-fé in order to observe the correct method of executing heretics. See Warner, 'The Climate of Exile', in Kingdoms of Elfin, pp. 152-168.

3. See Warner, 'Castor and Pollux', in Kingdoms of Elfin, pp. 176-91; 'Queen Mousie', in Sylvia Townsend Warner, One Thing Leading To Another (London: The Woman's Press Ltd, pp. 161-73; Warner, 'The Occupation', in Kingdoms of Elfin, pp. 192-207.

WORKS CITED

CROSSLEY, R. (1985) 'A Long Day's Dying. The Elves of J.R.R. Tolkien and Sylvia Townsend Warner'. Death and Immortality in Science Fiction and Fantasy. Ed. Yoke and Hassler. Westport CT and London, Greenwood Press, pp. 57-70.

PURKISS, D. (2001) At the Bottom of the Garden: A Dark History of Fairies, Hobgoblins and Other Troublesome Things. New York, New York University Press. 
SIMONS, J. (2006) 'On the Compositional Genetics of Kingdoms of Elfin, together with a Note on Tortoises'. Critical Essays on Sylvia Townsend Warner, English Novelist 1893-1978. Eds. Davis, Malcolm and Simons. New York and Lampeter, Edwin Mellen Press. pp.45-60 SUTHERLAND, H. (2005) 'From Elphame to Otherwhere: Sylvia Townsend Warner's Kingdoms of Elfin'. The Journal of the Sylvia Townsend Warner Society pp.21-31.

WARNER, S. T. (1979) Kingdoms of Elfin (1977) Harmondsworth, Penguin.

(1985) 'Narrative of Events Preceding the Death of Queen Ermine'. One Thing Leading to Another. London, The Woman's Press pp.148-160.

(1985)'Queen Mousie'. One Thing Leading to Another. London, The Woman's Press, pp. 161-73.

Virago.

(1987) [1936] Summer Will Show. London,

ZIPES, J. (2002) Breaking the Magic Spell: Radical Theories of Folk and Fairy Tales. Kentucky, University of Kentucky Press. 